\title{
FEELING OF BEING OUT OF PLACE: A CASE STUDY OF KAMPUNG IN BUMI SERPONG DAMAI, INDONESIA
}

\author{
DIAN ALIN MULYASARI \& ANTONY SIHOMBING \\ Department of Architecture, Universitas Indonesia, Indonesia
}

\begin{abstract}
This paper investigates the spatial experience of indigenous people in light of competing forces in the new urban growth area. It takes the case of urban growth in BSD City, Indonesia, which lies about $27 \mathrm{~km}$ to the western part of Jakarta. Within this new urban area, the capital forces of giant governmentbacked developer provide heavy pressure to kampung - the indigenous settlement. Several kampungs were displaced, while others exist after a series of struggles. However, those kampungs are spatially marginalized: access is limited and bounded by fences and walls from its surrounding. This study focuses on how kampung dwellers are experiencing their marginalized lived space in the transforming environment. The combined, the separation and the antagonism of dominated and appropriated space are investigated from the lenses of local people using cognitive mapping procedures. In order to reveal dweller experience, 17 out of 128 household head of a small kampung were taken as respondent. This study shows that although the indigenous people succeed in shaping urban spaces, qualitatively they were alienated from their new surroundings. This new city does not belong to their life. The feeling of being out of place becomes real as it has been constructed by new city developers.
\end{abstract}

Keywords: out of place, spatial experience, kampung.

\section{INTRODUCTION}

Henri Lefebvre in his seminal work stated that capitalism and neo-capitalism had produced abstract space, within which the town has disintegrated. One diversified, it opposed, sometimes complemented and sometimes resembled one another. Lefebvre differentiates such space as dominated and appropriated space. The dominated space - space transformed and mediated by technology, by practice and invariably the realization of a master's project - is usually closed, sterilized, emptied out. While the opposite is the concept of appropriated space, a space that resembles a work of art. Both may in principle be combined and, ideally at least, they ought to be combined. However, history - which is to say the history of accumulation - is also the history of their separation and mutual antagonism. The winner of this contest has been domination [1].

Depart from Lefebvre conception; this paper tries to explore the spatial experience of kampung dwellers which lies in the vortex of urban growth. Kampung, in the Indonesian language, refers to an indigenous settlement where the residents still practiced traditional ways, in their everyday life, as in their village, even though they were in an urban area [2]. Kampung represents an appropriated space. It is a natural space modified to serve the needs possibilities of a group that it has been appropriated by that group [1]. The case study was taken in Kampung Nagrek - BSD City, located $27 \mathrm{~km}$ to the western part of Jakarta (Fig. 1.).

Kampung Nagrek was a squatter settlement in the rural area. It consisted of rubber plantations, rice fields, farmland, sand mining and squatter settlement. The construction of BSD City has changed the landscape of its surrounding tremendously. Some neighbouring settlements have disappeared, transformed into luxurious residential clusters along class facilities to support them. The majority of indigenous people have been marginalized to the villages farther away. Those who remain in their houses are now facing a separate fence, 


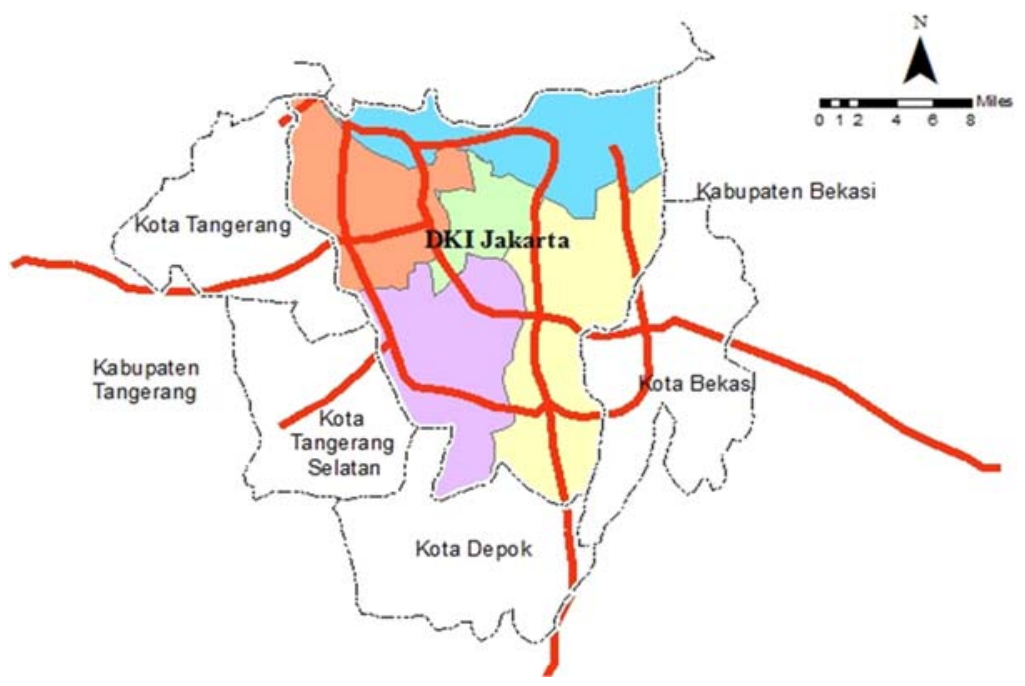

Figure 1: The study area.

wall, new housing, and roads [3]. Kampung Nagrek today is no longer a settlement regarding the rural area, rather it is a squatter settlement located in the new urban area.

Within this area, the contestation between dominated space of the new city and the appropriated space of kampung come into existence. The case of BSD City and Kampung Nagrek shows the combine, the separation and the antagonism of dominated space and appropriated space.

This study attempts to explore how the new changing urban space is experienced by the indigenous kampung dwellers within vast spatial and environmental transformation. It is become important to understand their spatial experience since the producing of urban space necessarily entails more than just planning the material space of the city. It involves all aspect of people's life [4]. It also includes a thought concept and feeling - an "experience" [5].

\section{SPACE AND SPATIAL EXPERIENCE: A THEORETICAL APPROACH}

"The present epoch will be above the epoch of space" [6]. What was predicted by Michel Foucault 50 years ago seems to be relevant today. Space is still a contentious concept. A different understanding of space underlies the separation of epistemology between a philosophical approach and spatial practice. Debates about the space can be traced back to Plato and Aristotle, Bergson and Einstein, Euclid and Carnap, Descartes, Leibniz and Kant, to Lefebvre, Foucault and others [5]. Plato is the first person to explicitly distinguish chora (space) and place [7]. According to Plato, space provides a container of everything. It is the womb, the nurse, the receptacle that provides the position of everything that will be. While the place is a comprehensible entity and can be perceived by the perceptual sense, "a sensible entity, it has come into existence, constantly in motion, apprehended by perception being" [8]. Subsequently, Aristotle reduced Chora to something immense (megethos) and named the place (topos) as the immobile content of the chora. Aristotelian topos concept is one part of the definition of the being of a physical thing [7].

After Plato and Aristotle, Descartes' thought became an important point in the discourse of the concept of space. In Cartesian logic, space has entered the absolute world, in line with the materialism nature of Cartes philosophy. Responding to the views of Descartes, then 
Immanuel Kant provides a revision of the concept of space [1]. Kant states that space is not an empirical concept but a subjective condition of the mind. "Space is not something objective and real, nor a substance; Instead, it is subjective and ideal, and originates from the mind's nature in accord with a stable law as a scheme, as it was, for coordinating everything sensed externally" [9]. Kant asserts that space (and time) is not an objective and independent reality. Space is a subjective demand of our sensory ability to make sure everything is in harmony. Space and time serve as an indispensable tool that regulates images of objects imported by sensory organs. The raw data supplied by the eyes and ears will be useless if the mind has no space and time to understand it all [10]. For Kant, space is one of the conditions/conditions of experience. Space is not palpable, but it is a medium in which humans feel the experience of an object [11].

The emergence of phenomenology introduced by Edmund Husserl has shifted the focus from the world out there or what is in reality to how human beings perceive and experience their space [7]. Since human is essentially spatial [12], therefore spatial experience will underline the meaning of peoples' lives as it is [13]. From the lenses of this approach, human beings not only discern geometric patterns in nature and create abstract spaces in mind, but they also try to embody their feelings, images, and thoughts in tangible material [14]. Space is not a series of abstract relations in which the world of life is structured. In contrast, the lived experience is the primary relationship from which all the conceptions of space are built [15]. In other words, people do not perceive space as it exists, but space which is lived [12].

One of the seminal works in investigating lived experience was conducted by Edward Relph's work in 1976. His contribution to the understanding of spatial experience is the concept of insideness and outsideness. To be inside is to belong to it and to identify with it, and the more profoundly inside the person feels, the stronger is this identity with the place [16]. If a person feels inside a place, he or she is here rather than there, safe rather than threatened, enclosed rather than exposed, at ease rather than stressed [17]. On the contrary, outsideness refers to a situation where a person is separated or alienated from their context. Here, people feel some sort of division between themselves and the world [17]. The similar concept of belongingness and identity were brought by Creswell. He introduced the terms 'in place' and 'out of place' to describe the situation when someone belongs to the particular place and not in another [18]. According to Cresswell, it is possible for someone to be inside or outside a place. Outsiders are not to be trusted; insiders know the rules and obey them. Since the place has an objective and subjective aspect, then according to Cresswell the insider and outsider do not simply refer to a location. Outsider is not just someone who is really from another location but someone who existentially does not know the rules [18].

This study attempts to expand the knowledge of urban lived experience when the dominated and appropriated space combine, separate and antagonize each other, by looking into the lives of the marginal element of the new city. In particular, this study investigates the spatial experience of kampung dweller through their perceptual and cognitive conception of their lived space.

\section{METHOD}

The study reported here is a part of broader research which investigates kampung dweller's spatial experience in the enormous urban growth. To understand the people's lived experience, we have to understand how the kampung dwellers' live, how do they connect with their world and how do they feel. This paper only focuses on the analysis of kampung dweller's perceptual and cognitive conception of their space. The cognitive conception of space understood through the map can help shape our perceptual knowledge, which in turn can characterize everyday spatial encounters as we move through the realm of the real world 
[17]. Therefore, this paper employs cognitive maps to reveal how dwellers understand and give the meanings of their daily lived space.

A cognitive map is an individual mindset or individual concept. It identifies representations of objects in the physical environment, the concept of surroundings, living beings, behavior, culture, identity, structure and meaning [2]. We asked the participants to sketch a cognitive map and gave them the opportunity to draw their spatial surroundings through their interpretation of the phrase 'the place where I live.' We intend to know how their space features, and how the spaces of the participants were viewed and used. Through cognitive map, we expect that participants can show what is important, and also reveal what is less important in their daily spaces. The maps produced illustrated not only the physical layout but also psychosocial connections occurred [19].

The participants in this study were Kampung Nagrek dwellers. In total, there were 17 people involved consisting 13 males and 4 females, with their age ranging from 20-79 years (Table 1).

Table 1: Participants' characteristics.

\begin{tabular}{|c|c|c|c|c|c|c|}
\hline \multirow{2}{*}{\multicolumn{2}{|c|}{$\begin{array}{c}\text { Participants } \\
\text { (not the real } \\
\text { name) }\end{array}$}} & \multirow{3}{*}{$\begin{array}{l}\text { Age } \\
44 \\
\end{array}$} & \multirow{3}{*}{$\begin{array}{l}\text { Sex } \\
\text { Male }\end{array}$} & \multicolumn{2}{|c|}{ Occupation } & \multirow{3}{*}{$\begin{array}{l}\text { Education } \\
\text { High school }\end{array}$} \\
\hline & & & & \multirow{2}{*}{$\begin{array}{c}\begin{array}{c}\text { Before city } \\
\text { development }\end{array} \\
\text { Farmer }\end{array}$} & \multirow{2}{*}{$\begin{array}{c}\text { Current job } \\
\text { Security }\end{array}$} & \\
\hline 1. & Mahfud & & & & & \\
\hline 2. & Sofyan & 30 & Male & Small trader & Small trader & Elementary \\
\hline 3. & Jamal & 33 & Male & Small trader & Small trader & High school \\
\hline 4. & Munaf & 50 & Male & Farmer & $\begin{array}{l}\text { Motorbike taxi } \\
\text { driver }\end{array}$ & Elementary \\
\hline 5. & Solihin & 50 & Male & Farmer & Cleaning service & Elementary \\
\hline 6. & Sukarta & 33 & Male & Small trader & Unemployed & Elementary \\
\hline 7. & Sarifudin & 59 & Male & Land broker & Trader & \\
\hline 8. & Tasdik & 79 & Male & Farmer, trader & Trader & -- \\
\hline 9. & Ma'sum & 52 & Male & Private driver & Private driver & Elementary \\
\hline 10. & Yunus & 60 & Male & Farmer & Unemployed & -- \\
\hline 11. & Siman & 60 & Male & Farmer & Unemployed & -- \\
\hline 12. & Anung & 20 & Male & Student & Small trader & High school \\
\hline 13. & Munar & 23 & Male & Student & Student & High school \\
\hline 14. & Ermy & 40 & Female & Housewife & Housewife & Elementary \\
\hline 15. & Sumarni & 44 & Female & Housewife & Housewife & Elementary \\
\hline 16. & Kokom & 35 & Female & Housewife & Housewife & Elementary \\
\hline 17. & Iyan & 50 & Female & Housewife & Housewife & -- \\
\hline
\end{tabular}




\section{RESULT}

\subsection{Participants' living environment}

Kampung Nagrek is one of the organic settlements that still survive in the midst of the growth of the new city. The village has undergone enormous environmental changes over a period of 10 years. Formerly this kampung was a squatter settlement in the rural area but now turned into a squatter settlement in the urban area. Although kampung Nagrek is currently located in a new urban area, the rural characteristics of the village have not changed. Fig. 2 shows the location of kampung Nagrek in the formation of a new city space. Differences in landscape and space elements appear to the contrast between the two. The kampung is still had rural atmosphere, characterized by lush naturally grown trees, traditional house shapes, the use of conventional building materials, and more organic house arrangements. On the contrary, the landscape of the new city is modern, neat, organized and equipped with premium city-class support facilities. It also characterized by a neat arrangement of trees, modern housing layout and the use of more premium materials. The difference in the materiality of the space makes Kampung Nagrek impressed as area out of place, which differs from its surrounding environment.

\subsection{Cognitive mapping of Kampung dwellers}

To obtain a picture of lived space experience of participants, we asked them to sketch "the place where I live" through a cognitive map. The maps were drawn without time limitation to avoid feelings of distress on the participants. We intend to know how their space features, and how the spaces of the participants were viewed and used. Through cognitive map, we expect that participants can show what is important, and also reveal what is less important in their daily spaces. Fig. 3 shows examples of cognitive maps sketched by participants.

\subsection{Seeing the city through the lenses of kampungs' dwellers}

Based on participants' cognitive maps, some essential elements are identified by looking at its appearance in the map. The presence of these elements are shown in Table 2.

Figure 4 displays the most frequent elements drawn by kampung dwellers. They are kampungs' lane (17); participants' house (17); Streets (12 out of 17); relatives' house (12 out of 17); Foresta/new residential area of new city (11); Tunnel as entry point to kampung (9); Mosque (8); Kampung Tegal/the neighbouring kampung (7); Informal leader house (4), Traffic Light (4).

Mapping the respondents' identification of "where I live" reveals interesting findings. Based on the responses, dwellers' maps reflect the fragmented nature of the city. There are no participants that demonstrate an "insideness" sense with the new city. From dwellers' maps, it can be seen that the most frequent elements occur is the elements of kampung, not the city. It informs us that kampung and its elements are the most important elements in their life. Moreover, none of the participants take the setting of a new city to describe their lived space. All of the participants only drew kampung Nagrek with its surrounding as their lived space. It means that kampung dwellers perceived their kampung and the city as different entities. The "outsideness" feeling also can be traced when none of them drew the city facilities, such as hospitals, schools, shopping malls, sport club, etc. Participants only drew some elements of the new city which directly linked to their kampung, such as streets as a channel for their movement, tunnel as the entrance to their kampung, Foresta as a 
residential area close to their kampung and traffic light near the entry of the kampung. Some participants even describe their lived space in the past area configuration setting, when the new city has not been built (Fig. 5).

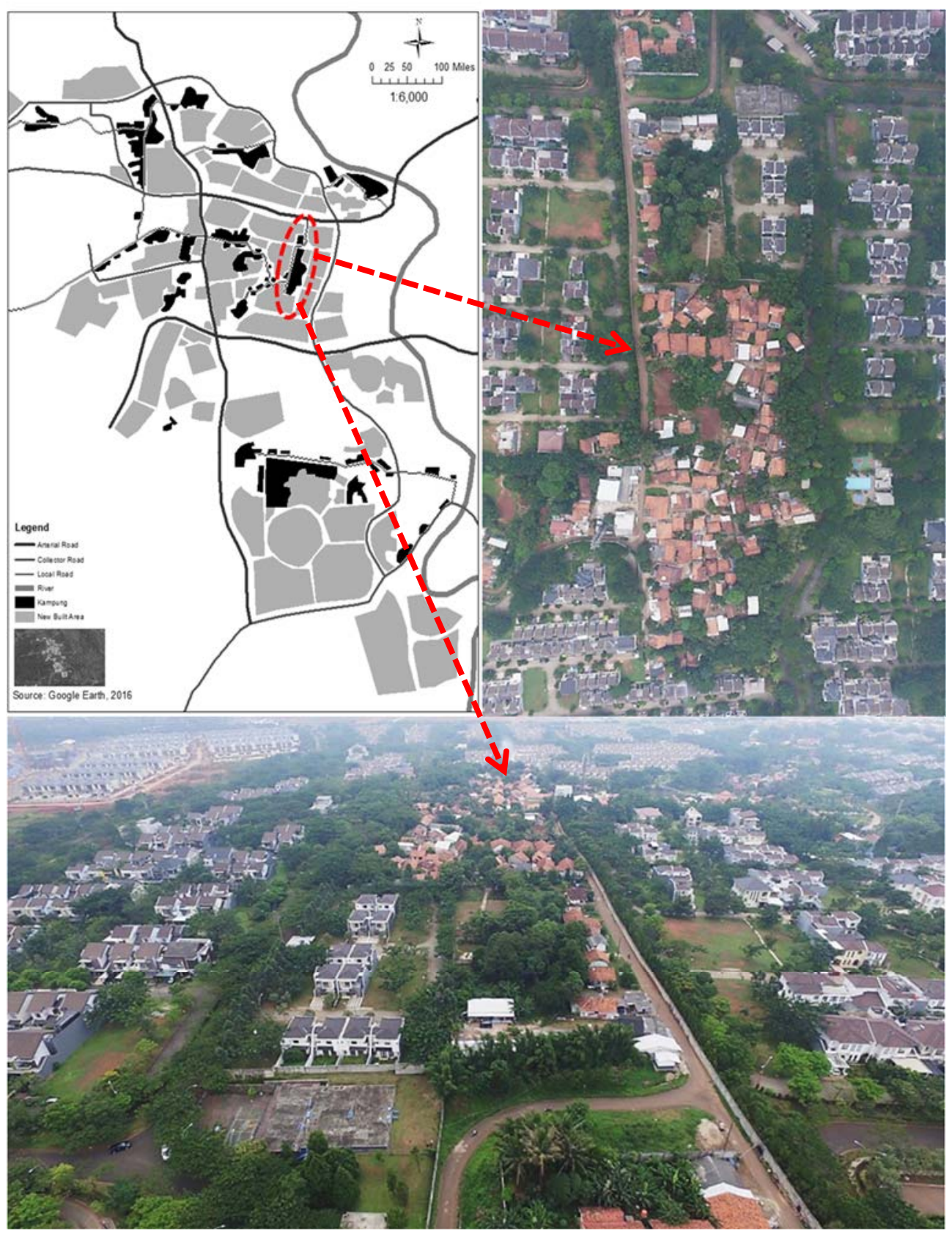

Figure 2: Kampung Nagrek in the new city. 


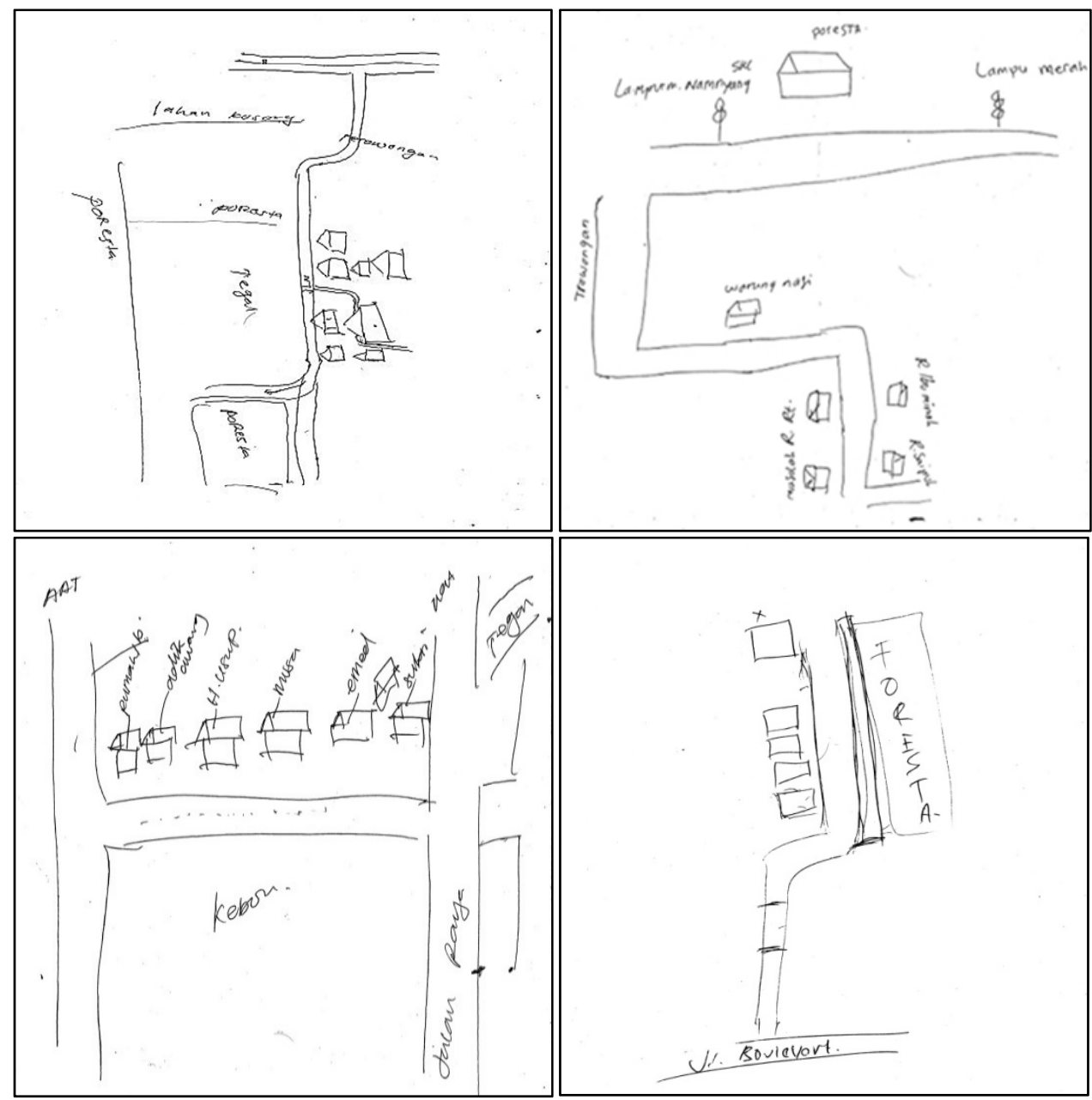

Figure 3: Cognitive maps of kampung dwellers.

Table 2: Elements of kampung dwellers' cognitive maps.

The elements of the New City

\begin{tabular}{|l|l|l|l|l|l|l|l|l|l|l|l|l|l|l|l|l|l|l|}
\hline $\begin{array}{l}\text { Participant } \\
\text { Element }\end{array}$ & 1 & 2 & 3 & 4 & 5 & 6 & 7 & 8 & 9 & 10 & 11 & 12 & 13 & 14 & 15 & 16 & 17 & \\
\hline Streets & \multicolumn{2}{|c|}{} & & & & & & & & & & & & & & & & 12 \\
\hline Foresta & & & & & & & & & & & & & & & & & 1 \\
\hline BSD City & & & & & & & & & & & & & & & & & & 4 \\
\hline Traffic Light
\end{tabular}


Table 2: Continued.

The elements of Kampung

\begin{tabular}{|c|c|c|c|c|c|c|c|c|c|c|c|c|c|c|}
\hline \begin{tabular}{|l|} 
Participant \\
Element
\end{tabular} & \begin{tabular}{l|l}
1 & 2 \\
\end{tabular} & \begin{tabular}{|l|l}
3 & 4 \\
\end{tabular} & 5 & 6 & 7 & 8 & \begin{tabular}{|l|l|}
9 & 10 \\
\end{tabular} & \begin{tabular}{l|l}
11 & 12 \\
\end{tabular} & 13 & 14 & 15 & 16 & 17 & \\
\hline Kampungs' lanes & & & & & & & & & & & & & & 17 \\
\hline Participants' house & & & & & & & & & & & & & & 17 \\
\hline Relatives' house & & & & & & & & & & & & & & 12 \\
\hline Tunnel & & & & & & & & & & & & & & 9 \\
\hline Mosque & & & & & & & & & & & & & & 5 \\
\hline Musholla & & & & & & & & & & & & & & 3 \\
\hline Informal leader house & & & & & & & & & & & & & & 4 \\
\hline Madrasah & & & & & & & & & & & & & & 1 \\
\hline Separating wall & & & & & & & & & & & & & & 1 \\
\hline Cemetery & & & & & & & & & & & & & & 2 \\
\hline Aas stall & & & & & & & & & & & & & & 3 \\
\hline Food stall & & & & & & & & & & & & & & 3 \\
\hline Garden & & & & & & & & & & & & & & 2 \\
\hline Unused land & & & & & & & & & & & & & & 1 \\
\hline Traditional sport field & & & & & & & & & & & & & & 2 \\
\hline Trash dump & & & & & & & & & & & & & & 1 \\
\hline Paddy fields & & & & & & & & & & & & & & 1 \\
\hline
\end{tabular}

The elements of surroundings.

\begin{tabular}{|c|c|c|c|c|c|c|c|c|c|c|c|c|c|c|c|c|c|c|}
\hline $\begin{array}{l}\text { Participant } \\
\text { Element }\end{array}$ & 1 & 2 & 3 & 4 & 5 & 6 & 7 & 8 & 9 & 10 & 11 & 12 & 13 & 14 & 15 & 16 & 17 & \\
\hline \multicolumn{18}{|l|}{ Kampung Tegal } & 7 \\
\hline Sampora Village & & & & & & & & & & & & & & & & & & 1 \\
\hline Cisauk District & & & & & & & & & & & & & & & & & & 1 \\
\hline Police Office & & & & & & & & & & & & & & & & & & 1 \\
\hline Pagedangan District & & & & & & & & & & & & & & & & & & 1 \\
\hline Legok District & & & & & & & & & & & & & & & & & & 1 \\
\hline Cicayur Village & & & & & & & & & & & & & & & & & & 1 \\
\hline Junior High School & & & & & & & & & & & & & & & & & & 1 \\
\hline Cisadane River & & & & & & & & & & & & & & & & & & 1 \\
\hline Paddy fields & & & & & & & & & & & & & & & & & & 1 \\
\hline
\end{tabular}

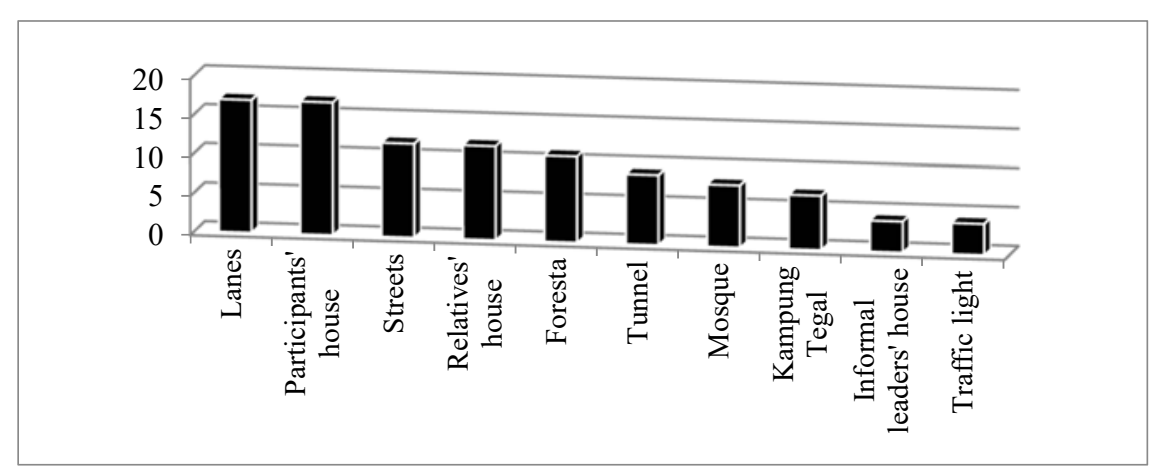

Figure 4: The most frequent elements in Dwellers' maps. 


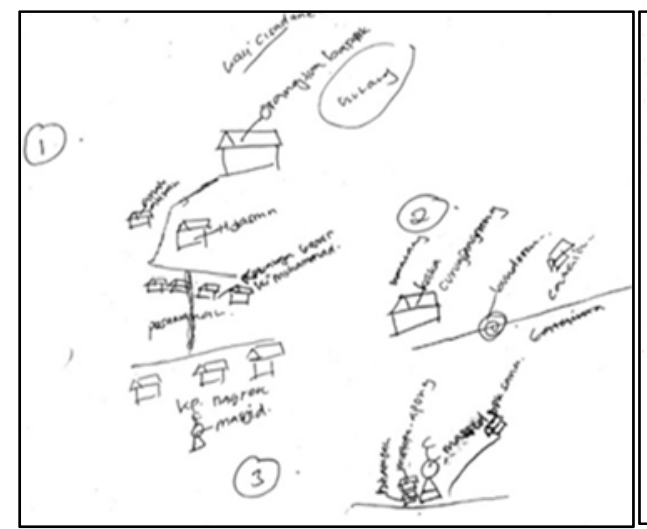

Map No. 11

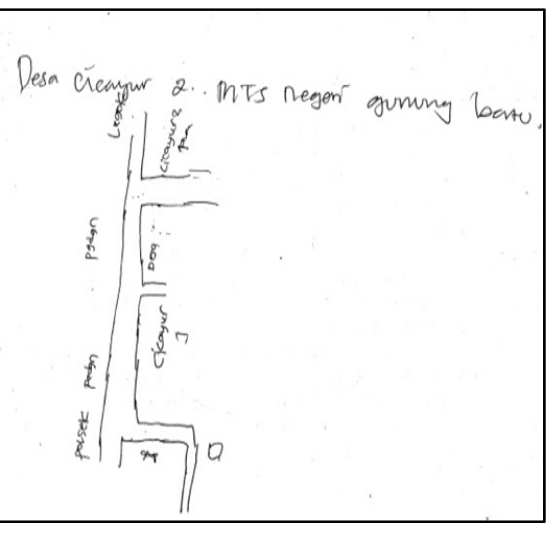

Map No. 17

Figure 5: Cognitive maps using past area configuration setting.

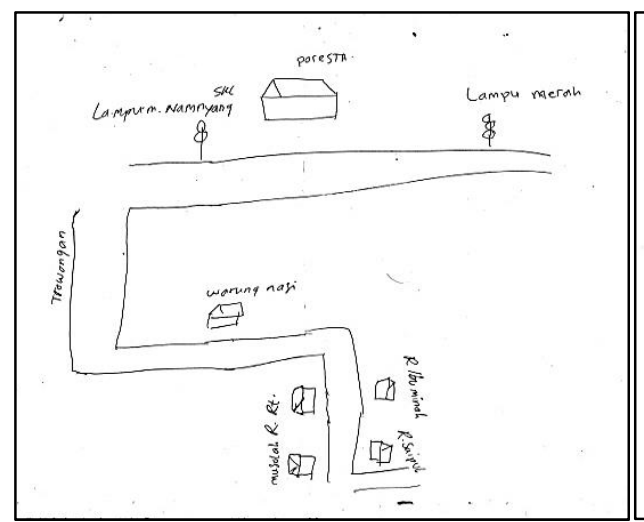

Map No. 10

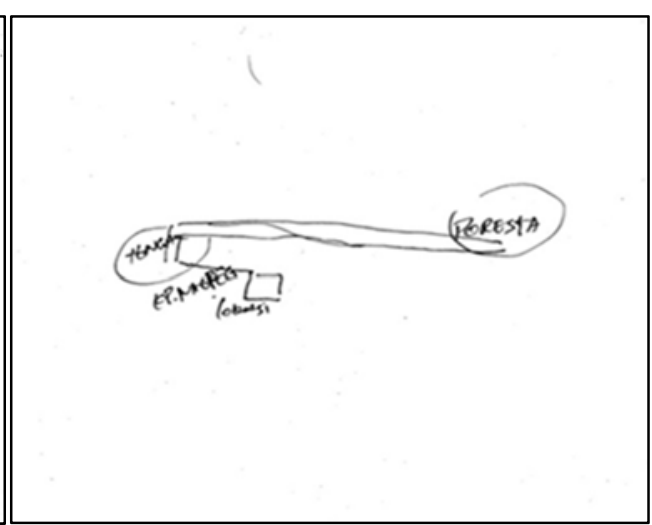

Map No. 7

Figure 6: The Perceptual home zone of participants.

The results of mapping the respondents' indications of their home also reveal significant findings. Home is not just a house people happen to live in, it is not something that can be anywhere, that can be exchanged, but an irreplaceable center of significant [16]. In the case of kampung Nagrek dwellers, most participants did not realize that their home zone is in the middle of Foresta - one of a residential area in new city - as displayed in Fig. 6. From 17 participants, 11 participants drew Foresta as spatial elements of their daily spaces. While the rest do not consider that their homes are located near to Foresta. However, 8 out of 11 participants define their home in the sense of backwardness. Only 3 persons realize that Foresta surrounds their homes.

\section{CONCLUSION}

The findings generated from implementing cognitive mapping helped to contribute to understanding the kampung dwellers' spatial experience in the new city. The cognitive maps 
produced by kampungs' dwellers reflect the segregated nature of the city. It can be seen from the facts that there are no participants who strongly demonstrate an 'insideness' with the new city. Being inside is knowing where you are [16]. Therefore, if a person feels inside a place, he or she is here rather than there, safe rather than threatened, enclosed rather than exposed, at ease rather than stressed [17]. In this study, we found that participants do not recognize the position of their lived space in urban formation. It indicates that kampung dwellers perceived their kampung and the city as different entities. None of them took the new city in describing their lived space context. Rather, they perceived the lived space in the scope of kampung and its former rural area. They understand the position of their own houses, their relatives' house, and the boundary of their kampung, as they are significant in defining participants' lived space. This study also reveals that although physically participants dwell in urban space, mentally they do not belong in that space. The feeling of being out of place becomes real as new city developers have constructed it.

\section{REFERENCE}

[1] Lefebvre, H., The Production of Space, Translated by Donald Nicholson-Smith, Blackwell Publishers Ltd., Oxford, pp. 53-166, 2001.

[2] Sihombing, A., Conflicting Images of Kampung and Kota in Jakarta: The Differences and Conflicts, and The Symbiotic Links between Kampungs and Kota, Lambert Academic Publishing, 2010.

[3] Mulyasari, D.A., Sihombing, A. \& Isnaeni, H., Negotiating an Urban Form: The Struggle of A Concealed Kampung (Kampong) In A New City Development, WIT Press, 2017.

[4] Purcell, M., Excavating Lefebvre: The right to the city and its urban politics of the inhabitant, GeoJournal, 58(2),(3), Social Transformation, Citizenship, and the Right to the City, p. 102, 2002.

[5] Goonewardena, Space, Difference, Everyday Life, Routledge, New York and London, p. 41, 2008

[6] Foucault, M., The Espace Autres, The French journal Architecture /Mouvement/Continuité October 1984, A lecture given by Michel Foucault in Mar 1967, 1984.

[7] Perdikogianni, I., From Space To "Place": The Role of Space and Experience in The Construction Of "Place", University College London, London, p. 6, 2007.

[8] Plato, Timaeus \& Critias, Translated with an Introduction and an appendix on Atlantis by Desmon Lee, Penguin Books, p. 71, 1971.

[9] Janiak, A., Kant's Views on Space and Time, Stanford Encyclopedia of Philosophy, 2016.

[10] Ben-Zvi, P., Kant on Space, Philosophy Now, 2005.

[11] Theodorou, M., Space as Experience: Chore/Choros, AA Files No. 34, Architectural Association School of Architecture, p. 47, 1997.

[12] Heidegger, M., Being and Time, Blackwell, Oxford \& Cambridge, pp. 143, 2001.

[13] Gunawaradana, D., Urban Space and Spatial Experience: An Exploratory Study, University of Moratuwa, 1997.

[14] Tuan, Y.F., Space and Place: The Perspective of Experience, University of Minnesota Press, Minneapolis, 2001.

[15] Tilley, C., A Phenomenology of Landscape, Berg, Oxford, p. 14, 1994.

[16] Relph, E., Place and Placelessness, Pion Limited, London, p. 49, 1976.

[17] Seamon, D. \& Sowers, J.D., Place and Placelessness, Edward Relph, Key Texts in Human Geography, P. Hubbard, R. Kitchen, \& G. Vallentine, eds., Sage, London. p. 3, 2008.

[18] Cresswell, T., In place/out of place: Geography, ideology, and transgression, University of Minnesota Press, Minneapolis, 1996.

[19] Buzinde, C.N. \& Navarrete, D.M., the social production of space in tourism enclaves: Mayan children's perceptions of tourism boundaries, Annals of Tourism Research, 43, pp. 482-505, 2013. 